\title{
Research \\ Poverty and Environmental Services: Case Study in Way Besai Watershed, Lampung Province, Indonesia
}

\author{
$\underline{\text { S. Suyanto }}^{1}, \underline{\text { Noviana Khususiyah }}^{1}$, and Beria Leimona ${ }^{1}$
}

\begin{abstract}
Local communities in developing countries are often forbidden to earn their livelihood from stateowned forests, but nonetheless local people commonly manage these lands and depend on them to survive. In these places, community participation is the key to successful conservation programs intended to rehabilitate environmental functions and produce environmental services for beneficiaries outside the area. This paper reviews the relationship between poverty and environmental services and briefly discusses the main ways in which approaches that rely on payment for environmental services are thought likely to alleviate poverty. It also discusses the poverty profile and inequality of upland dwellers in the Sumberjaya watershed in Indonesia's Lampung Province, using income, education, and land-holding indicators. Data related to these three indicators were collected from intensive household surveys and interviews and used via Gini decomposition to measure inequality. In addition, analysis of data on stem at breast height and horizontal root diameter of coffee and other noncoffee trees planted on coffee farms showed that index of root shallowness could be used as an estimator of environmental services. This study revealed that state forest land in Lampung Province, Indonesia, not only provides important income for poor farmers but also leads to a more equitable distribution of income and land holdings. These farmers have also successfully rehabilitated degraded land by establishing coffee-based agroforestry. As found in other recent studies, these findings show that coffeebased agroforestry can perform watershed service functions similar to those of natural, undisturbed forests. This supports the argument that poor farmers who provide environmental services through their activities in state-owned forests should be rewarded with land rights as a policy to alleviate poverty.
\end{abstract}

Key Words: coffee trees; agroforestry; environmental services; equity; poverty; payment for environmental services; watershed; Lampung Province; Indonesia

\section{INTRODUCTION}

Poverty is a fundamental global problem. In 1990, $28 \%$ of people in developing countries lived in extreme poverty, i.e., on less than U.S. $\$ 1.00 /$ d. However, the United Nations Millennium Development Goal of halving the percentage of people living in extreme poverty by 2015 has generated various initiatives to improve the situation. Achieving the goal means reducing the number of poverty-stricken people from 1.2 billion in 1990 to 890 million; globally, the number is falling. However, progress varies widely between regions. Asia in general is reportedly making good progress but still has pockets of disadvantage. Although the Asia Pacific region has made impressive economic gains, two-thirds of the world's poor live in this region, and 14 Asia Pacific countries are still classed as developing countries.
Indonesia is a case in point. After three decades of growth, the economic crisis that began in mid-1997 reversed the gains the nation had made in its efforts to alleviate poverty. In 1996 , only $11 \%$ of the population were classed as poor; in 2004, this proportion had risen to $16.6 \%$. The problem is compounded by Indonesia's struggle with other difficulties such as natural disasters, disease outbreaks, and unsustainable resource use that degrades the environment. The rural population, whose livelihood depends on agriculture and forestry, is the worst affected and most economically marginalized; $76 \%$ of Indonesians living below the poverty line in 1999 were in rural areas (Pradhan et al. 2000).

Farmers rely on natural resources, including stateowned forests, for their livelihood. Furthermore, conservation benefits the wider population because these resources provide important environmental 
services such as clean, reliable water supplies. In the past, Indonesian forest policies intended to conserve resources failed because the poor communities living in the forests were not involved in government conservation programs. Local examples abound. For example, in Lampung Province on the tip of Sumatra Island, the forest rehabilitation program evicted farmers, cut down the understory coffee trees that were their main source of income, and replaced them with Kaliandra (Calliandra colothyrsus), a native tree species, for conservation purposes. This program has caused ongoing conflict and worsened local poverty while the forest land itself has continued to degrade.

Rewarding poor farmers for the environmental services they provide could be a solution. The World Agroforestry Centre (ICRAF) leads an action research program to develop mechanisms in Asia for Rewarding Upland Poor for Environmental Services (RUPES). This program contends that many poor upland and mountain communities in Asia manage landscapes that provide environmental services to outside beneficiaries. The services include clean and abundant water supplies from watersheds, biodiversity protection, and carbon stores that may alleviate global warming. The RUPES program takes an inclusive view on payment to distinguish a broader class of mechanisms in payment for environmental services (PES).

This paper begins by reviewing the relationship between poverty and environmental services and briefly discussing the main ways in which PES approaches are thought likely to alleviate poverty. It then discusses the poverty profile and inequality of upland dwellers in the Sumberjaya watershed in Indonesia's Lampung Province, using income, education, and land holding indicators. Sixty randomly selected households in two communities were intensively surveyed and interviewed, and the results showed that, based on these three indicators, the farmers at the study sites were poor.

From the household data compiled, we used Gini decomposition, a common method in economic analysis, to measure inequality. The results suggest that the income from coffee grown on state land is relatively equally distributed, making this income important for reducing poverty and increasing income equality. On the other hand, coffee income from private land and tenancy and nonfarm income lead to more unequal income distribution.
The analysis of index of shallowness using the data related to stem at breast height and horizontal root diameter of coffee and other noncoffee trees planted on coffee farms implies that coffee multistrata provide better environmental services through water and soil conservation than do sun coffee and simple shade systems. These multistrata systems also retain soil nutrients by reducing and minimizing the risk of landslides. Finally, the study indicates that the land management techniques practised by the poor in upland areas can improve environmental services.

\section{Poverty, environmental services, and payment for environmental services}

Van Noordwijk (2005) recognized that poverty indicators vary depending on the intensity of land use. At some stages, forest destruction provides the financial resources to reduce poverty but, at other times, environmental degradation becomes a determinant of poverty. Four continuous major scenarios were identified in which land use, environmental services, and poverty were linked:

1. The situation of "indigenous" people living in and around remote forests or natural reserves that are rich in globally significant biodiversity and have high carbon stocks and intact watersheds. Poor access to markets and public services such as health and education and the lack of representation in policy debates are poverty indicators in these areas.

2. The situation of local and migrant people who live in forest conversion zones or agroforest areas that still potentially have globally significant biodiversity; moderately high, but threatened, carbon stocks; and moderately functional watershed areas. Poverty is characterized by low access to public services and little voice in policy debates.

3. The situation of local and migrant people on degraded land, often with insecure tenure and low productivity, indicating food insecurity and low carbon stocks as well as poor watershed functions.

4. The situation of people in landscapes under rehabilitation. A partial restoration of agrobiodiversity, carbon stocks, and watershed 
functions emerges, followed by poverty alleviation. However, a retreat to the third stage is still possible.

Pagiola et al. (2005) examined the main ways in which payment for environmental services might affect poverty. In fact, the PES approach was originally conceptualized and used as a mechanism to improve the efficiency of natural resource management, not as a mechanism for alleviating poverty. The PES approach is based on the principle that those who provide environmental services should be compensated, and those who receive the services should pay for their provision (Pagiola and Platais 2002).

The logic is simple. Land users often receive few benefits from environmentally benign land uses such as forest conservation, and often fewer than from alternative land uses such as intensive agriculture. However, the environmental degradation resulting from converting forest land can impose costs on downstream populations that will no longer receive the benefits of ecological services such as water filtration. A payment by the downstream users can help to make conservation the more attractive option for those living upstream. The payment must be more than what the upstream communities would gain from the alternative nonconservation land use or they will not change their behavior and less than the value of the benefit to downstream populations or they will not be willing to pay for it. In relation to the four typologies above, moving toward environmentally benign land use may reduce farmers' ability to reap maximal profit from their current practice, at least in the short term.

PES programs are not a "magic bullet" for relieving poverty, but there can be important synergies when program design is well thought-out and local conditions are favorable (Rosa et al. 2004, Pagiola et al. 2005). A recent study by Suyanto et al. (2005) in a protected forest area in Lampung Province, Sumatra, Indonesia, found that the community has improved its sustainable land management. The main incentive is secure land rights that enable farmers to carry out more sustainable and protective activities. Even in areas in which forests are already degraded, local communities with secure tenure rights can rehabilitate these unproductive areas into more productive and sustainable systems. Mechanisms to reward the poor for the environment services that they provide need to be developed and promoted. Land tenure can be an attractive incentive or reward for farmers to sustainably manage protected forest land. Within the RUPES program, the payment need not be exclusively financial, but can instead take the form of in-kind payment, such as public services and land security. However, the appropriate mechanism for distributing the payment itself still needs further investigation, to avoid "free riders" and other disincentives.

\section{STUDY SITE AND METHODS}

Sumberjaya, which means "source of wealth, \&\#8221 is a subdistrict in the Bukit Barisan mountain range. These mountains span the west coast of Sumatra and form the upper watersheds of all the major rivers on the island. The 55,000-ha subdistrict almost coincides with the Way Besay upper watershed between $720 \mathrm{~m}$ and $1900 \mathrm{~m}$. The population was about 80,000 people in 1998 , with a density of about 150 people $/ \mathrm{km}^{2}$. About $40 \%$ of the subdistrict is classified as "protection forest" and about $10 \%$ as national park. Nevertheless, coffee gardens, also known as multistrata coffee, now cover about $70 \%$ of the total area.

The Way Besay watershed feeds the Tulang Bawang River, one of Lampung Province's three major rivers, along with the Way Sekampung and Way Seputih. The Way Besay also supplies a hydroelectric run-off dam owned by PLTA Way Besay. Electricity generation started in 2001, but was interrupted in 2002 by a landslide near the turbines. The landslide was linked to a poorly designed and built road, but was generally blamed on deforestation.

Sumberjaya is a benchmark for conflicts involving forest watershed functions in Indonesia. One of the most intensive "eviction" episodes occurred there and led to increased poverty among squatter families. Research suggests that these evictions, sometimes referred to as punishing upland people and their environmental services or PUPES, were based on an incomplete understanding of the underlying issues. Getting the watershed functions right in Sumberjaya may not only solve a local problem but also set a fine example that can be followed elsewhere.

Two upstream communities living in the Leuwi Monyet and Rigis Jaya subvillages, which are part of the Simpang Sari and Gunung Terang villages respectively, were selected for the household 
poverty assessment (Fig. 1). Leuwi Monyet is located in the Way Petai subcatchments and Rigis Jaya in the Way Kumpai subcatchments of Way Besai. These research sites could be considered to fit the third situation described in the typology of Van Noordwijk (2005). Multistrata coffee is an important economic activity in both communities.

In 2004, intensive household surveys and interviews were conducted in the upper parts of the Way Petai and Way Kumpai subcatchments. Sixty sample households were selected randomly. To measure inequality, the method of Gini decomposition was applied to the household data compiled. This method is commonly used in economic analysis (Alderman and Garcia 1993). The Gini formula is explained in Appendix 1.

Van Noordwijk et al. (2004) argued that multistrata coffee is a type of kebun lindung or "protective garden" that can provide environmental services and simultaneously improve farmers' welfare. Kebun lindung is a tree-based system managed by farmers that provides environmental services similar to those of forests. Kebun lindung does not refer to the legal status of the land but to the de facto watershed functions and soil protection provided by many types of gardens or agroforestry systems.

Two environmental services are water and soil conservation. The index of shallowness (IS) developed by Van Noordwjik and Purnomosidhi (1995) can be used to value the water and soil conservation benefits of coffee multistrata systems as follows:

(1). Index of shallowness (IS) $=D^{2}$ stem $/ \sum D^{2}$ horizontal root

where Dstem $=$ stem diameter measured at breast height or $1.3 \mathrm{~m}$ above the ground, and Dhorizontal Root $=$ diameter of the horizontal root.

A low IS indicates a shallow tree root that is important for reducing soil erosion. A high IS indicates a deep root that helps to sustain soil nutrients and prevent landslides.

\section{RESULTS AND DISCUSSION}

\section{Poverty level: income, land holding, and education}

The three indicators used to assess poverty levels at the study sites were income, land holding, and education level. The total income per year per household in Rigis Jaya was slightly higher than in Leuwi Monyet (Table 1). The composition of income sources, however, was similar. Farms were the major income source in both communities (64$70 \%$ ), with income from coffee gardens the most important. However, farmers at Leuwi Monyet were more dependent on income from state forest land $(41 \%)$ compared with those of Rigis Jaya (20\%). The share of farm income from private land was the highest in Rigis Jaya (31\%). Tenancy was uncommon, accounting for just 3\% of income. Nonfarm income made up less than $10 \%$ of the total. Income from agricultural wages was more important than nonagricultural labor for both Leuwi Monyet and Rigis Jaya.

The daily income per capita of respondents in Leuwi Monyet and Rigis Jaya was 4636 Rupiah (U.S. \$0.51) and 5162 Rupiah (U.S. \$0.68), respectively, and average family size was 3.97-4 at both sites. Thus we can conclude that farmers at Leuwi Monyet and Rigis Jaya were living below the international poverty line of U.S. $\$ 1.00 / \mathrm{d}$. Income from coffee gardens is important for farmer livelihoods at both sites. Most coffee gardens are classified as coffee multistrata, in which coffee is intercropped with two or more shading trees or other trees with direct economic benefits, or with annual crops. The share of total income from noncoffee crops was similar for farmers in both Leuwi Monyet and Rigis Jaya. However, the share from tree crops was higher in Leuwi Monyet, and the share from annual crops was higher in Rigis Jaya.

Family labor in the coffee gardens amounted to 108146 person-d/yr, with women doing $28-30 \%$ of the work. The income per family laborer is approximately 28,000-30,000 Rupiah (Table 2). A simple indicator of male bias in income was calculated (Male bias $=M-F / M+F)$, where $0=$ full equity and values up to 1 indicate male bias. The resulting male bias in income is moderate and in line with the reported labor gender divide in coffee farming (70\% male and $30 \%$ female). 
Fig. 1. Location of study site.

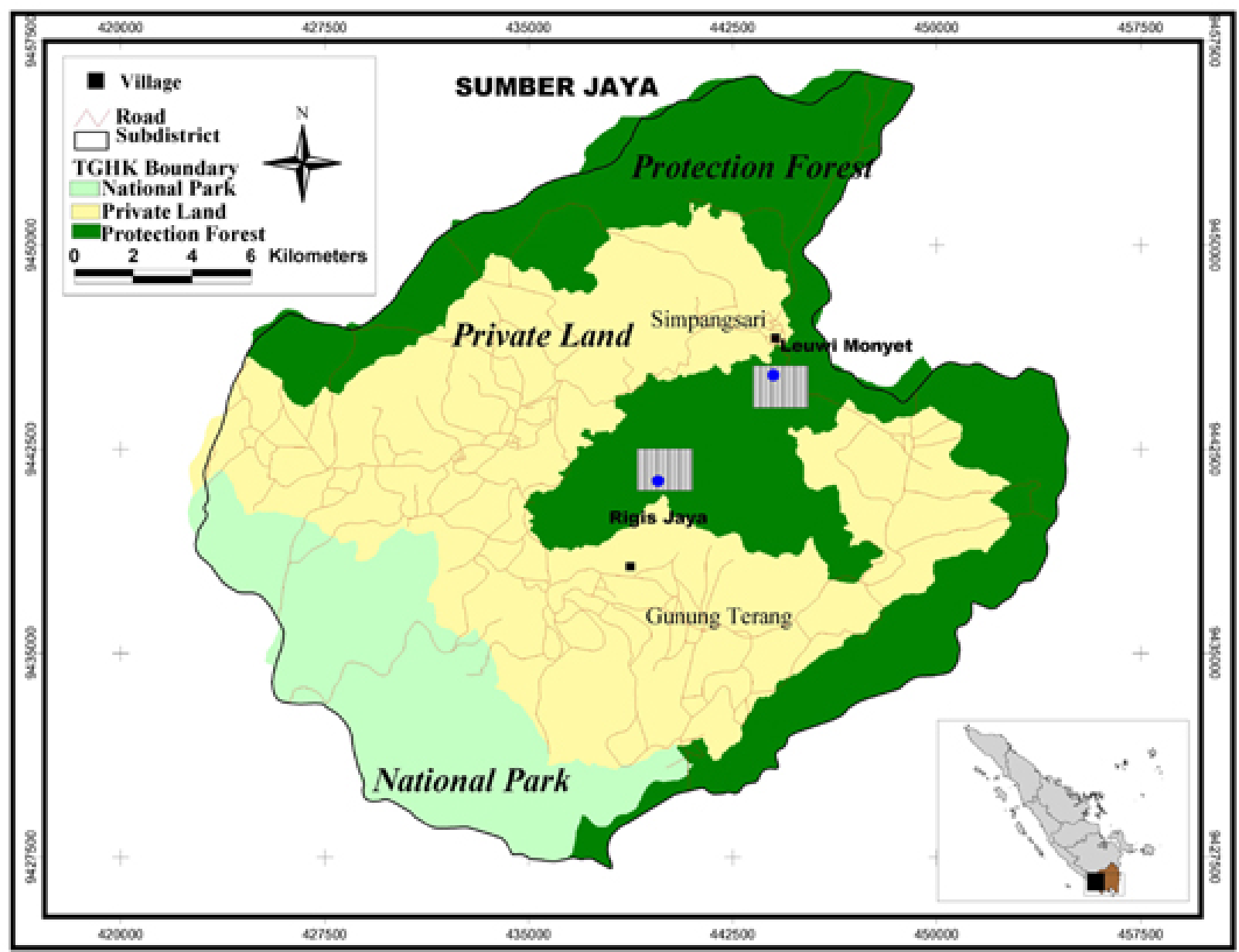

The average size of Leuwi Monyet land holdings (2.75 ha) was larger than the average in Rigis Jaya (2.27 ha). Leuwi Monyet farmers were more dependent on land inside the protected forest area (87\%), whereas Rigis Jaya farmers had only $55 \%$ of their land holdings inside the protected area. Coffee-based systems accounted for $73 \%$ of total land holdings for Leuwi Monyet farmers and $87 \%$ for Rigis Jaya farmers. The remaining land holdings area comprised bush or Imperata grasslands and irrigated rice fields.

The intensive household survey found that most respondents, which included both husband and wife, had a low education level: about $73 \%$ of respondents in Leuwi Monyet and 83\% in Rigis Jaya had less than or equal to six years of elementary schooling. The education level in Rigis Jaya was lower than in Leuwi Monyet (Table 3). The mean length of schooling ranged from 4.91 to $6.1 \mathrm{yr}$, which was lower than the average mean $(6.6 \mathrm{yr})$ at the provincial level in 2001, according to the monitoring database of the United Nations Support Facility for Indonesian Recovery. Nevertheless, the $3 \%$ illiteracy rate for Leuwi Monyet farmers was lower than the provincial level $(8.94 \%)$ in 2001 (Biro Pusat Statistik 2002). The illiteracy rate in Rigis Jaya, however, was very high (13-17\%). There was no significant difference in education level between men and women. 
Table 1. Source of Income in Way Besay Watershed Lampung in 2004.

\begin{tabular}{|c|c|c|c|c|c|c|}
\hline \multirow{3}{*}{ Sources of income } & \multicolumn{4}{|c|}{ Income per household } & \multicolumn{2}{|c|}{ Income per capita } \\
\hline & \multicolumn{2}{|c|}{ Leuwi Monyet } & \multicolumn{2}{|c|}{ Rigisjaya } & \multirow{2}{*}{$\begin{array}{c}\text { Leuwi Monyet } \\
\text { Rupiah }\end{array}$} & \multirow{2}{*}{$\begin{array}{c}\text { Rigisjaya } \\
\text { Rupiah }\end{array}$} \\
\hline & Rupiah & $\%$ & Rupiah & $\%$ & & \\
\hline \multicolumn{7}{|l|}{ A. Farm income } \\
\hline Coffee garden on state land & $2,732,748$ & 41 & $1,510,197$ & 20 & 688,350 & 368,341 \\
\hline Coffee garden on private land & 908,467 & 14 & $2,373,093$ & 31 & 228,833 & 578,803 \\
\hline Coffee garden with tenancy & 0 & 0 & 268,513 & 3 & 0 & 65,491 \\
\hline Rice field on state land & 411,493 & 6 & 75,947 & 1 & 103,651 & 18,524 \\
\hline Rice field on private land & 0 & 0 & 48,897 & 1 & 0 & 11,926 \\
\hline Rice field with tenancy & 25,562 & 0 & 0 & 0 & 6439 & 0 \\
\hline Other farm income & 623,767 & 9 & 613,870 & 8 & 157,120 & 149,724 \\
\hline B. Nonfarm income & 645,933 & 10 & 531,533 & 7 & 162,704 & 129,642 \\
\hline \multicolumn{7}{|l|}{ C. Wages } \\
\hline Agriculture & 874,250 & 13 & 835,000 & 11 & 220,214 & 203,659 \\
\hline Nonagriculture & 225,000 & 3 & 407,167 & 5 & 56,675 & 99,309 \\
\hline \multicolumn{7}{|l|}{ D. Other income } \\
\hline Transfer & 130,667 & 2 & 326,333 & 4 & 32,914 & 79,593 \\
\hline Sharecropping & 140,167 & 2 & 734,000 & 10 & 35,307 & 179,024 \\
\hline E. Total income per year & $6,718,054$ & 100 & $7,724,550$ & 100 & $1,692,205$ & $1,884,037$ \\
\hline F. Income per day & 18,507 & & 21,280 & & 4636 & 5162 \\
\hline
\end{tabular}

\section{Income and land holding inequality}

The previous assessment showed that farmers at the study sites were poor when judged by their income, land holdings, and education. We then turned to the question of how encroaching on state forest land has resulted in inequitable distribution of income and land holdings. We applied a decomposition analysis of the Gini coefficient, ranging from 0 (equal distribution of income) to 1 (total concentration of income).
The computation results of the decomposed Gini ratios of income are shown in Table 4 . The overall Gini ratios of income for Leuwi Monyet (0.38) and Rigis Jaya (0.30) are relatively small. This indicates that income at both sites was equally distributed

Income from coffee grown on state land reduced the overall inequality of income distribution at both sites, because the concentration coefficients were less than unity. This suggests that the income from coffee grown on state land is relatively equally 
Table 2. Annual household income from coffee gardens in Way Besay Watershed Lampung in 2004. Monetary values are given in Rupiah.

\begin{tabular}{lcc}
\hline \hline & Leuwi Monyet & Rigis Jaya \\
\hline Inside protection forest & & $1,557,047$ \\
Total income coffee garden & $2,657,183$ & 86 \\
$\%$ coffee & 86 & 10 \\
$\%$ annual crop & 3 & 5 \\
$\%$ tree crop & 10 & $2,594,757$ \\
Outside protection forest & 908,467 & 82 \\
Total income coffee garden & 83 & 5 \\
$\%$ coffee & 0.1 & 13 \\
$\%$ annual crop & 17 & $4,151,803$ \\
$\%$ tree crop & $3,565,650$ & 146 \\
Total income & 108 & 30 \\
Family labor used & 28 & 1.97 \\
$\%$ Female & 2.03 & 28,437 \\
Average area per household (ha) & 33,015 & \\
Return to family labor & & 5 \\
\hline
\end{tabular}

distributed, making this income important to reducing poverty and increasing income equality. On the other hand, coffee income from private land and tenancy leads to more unequal income distribution. Wealthy farmers often extend their private land through purchasing, which seems to have concentrated income from private land in the hands of fewer people. Tenancy was not common at either Leuwi Monyet or Rigis Jaya, with only a few farmers in both subvillages obtaining land under tenancy arrangements through connections with family and friends.

Income from growing rice was more evenly distributed at both sites, but accounted only for a small proportion of total income (2-6\%). All the rice fields in Leuwi Monyet and $50 \%$ of the rice fields in Rigis Jaya were on state forest land. Nonfarm income was more unequally distributed at both sites. Income from nonfarm activities accounted for $10 \%$ of total income for Leuwi Monyet and 7\% for Rigis Jaya. Most nonfarm income came from professional work requiring higher skills, higher education, and large capital, such as traders, ojeks (rented motorcycle transportation), coffee processors, and commissioners. Therefore, nonfarm income widens income disparities between individuals and households in the community.

Wages from agriculture make up a very important share of total income $(11-13 \%)$, and the 
Table 3. Percentage of households by year of schooling of household head in Way Besay Watershed Lampung in 2004.

\begin{tabular}{|c|c|c|c|c|c|c|c|}
\hline \multirow[t]{2}{*}{ Villages } & \multirow[t]{2}{*}{$n$} & \multicolumn{4}{|c|}{ Years of schooling (\%) } & \multirow{2}{*}{$\begin{array}{l}\text { Mean years of } \\
\text { schooling }\end{array}$} & \multirow[t]{2}{*}{$t$ test } \\
\hline & & Illiterate & $\begin{array}{l}\text { Attended } \\
\text { elementary } \\
\text { school }\end{array}$ & $\begin{array}{l}\text { Finished } \\
\text { elementary } \\
\text { school }\end{array}$ & $\begin{array}{l}\text { Attended } \\
\text { high } \\
\text { school }\end{array}$ & & \\
\hline \multicolumn{8}{|c|}{ Leuwi Monyet } \\
\hline Male & 30 & 3 & 30 & 40 & 27 & 6.1 & $t$ stat $=0.10$ \\
\hline Female & 30 & 3 & 21 & 59 & 17 & 5.9 & $(P>\mathrm{ItI}=0.58)$ \\
\hline
\end{tabular}

Rigis Jaya

$\begin{array}{llllllll}\text { Male } & 30 & 17 & 37 & 30 & 17 & 4.9 & t \text { stat }=0.55 \\ \text { Female } & 30 & 13 & 27 & 37 & 23 & 5.5 & (P>\mathrm{ItI}=0.92)\end{array}$

concentration coefficient is lower than unity for both sites, which implies more equal distribution. It is important to point out that agricultural labor is a very important income source for poor farmers, and this also implies that this work is more available for poor farmers. The share of income from nonagricultural work is lower for both previous and recent migrants $(3-5 \%)$. This indicates that the availability of nonagricultural work is very low for this population group. The impact on income equity differs, with the gap narrowing in Leuwi Monyet but widening in Rigis Jaya.

Little money was transferred from relatives living outside the villages, with this source accounting for just $2-4 \%$ of income. However, it has the effect of decreasing the inequality of distribution. This result was unexpected, because we expected money transfers from outside the villages to widen income equity.

The pseudo Gini ratios of land holding were 0.39 for Leuwi Monyet and 0.32 for Rigis Jaya (Table 5). Those Gini ratios are relatively small, which indicates that land is relatively evenly distributed.
This study revealed that the concentration coefficient of state land is less than unity for both Leuwi Monyet and Rigis Jaya, indicating that the use of state land reduced inequality. This implies that state land is relatively equally distributed. State land is relatively more available or accessible than private land. It is important to point out that state land is a very important source of land holdings for poor farmers. Migrants, particularly family and friends, followed the pioneers who succeeded in growing coffee. Through such connections, these migrants were able to claim the state land for free or pay small amounts of money as compensation to the farmers who had cleared and claimed the state land.

On the other hand, private land tends to increase inequality, because the concentration coefficients are more than unity. Most private land was purchased, which seems to have resulted in private land holdings being unequally distributed.

The impact of tenancy on income equity was ambiguous. It reduced inequality in Leuwi Monyet but increased it in Rigis Jaya. Tenancy was arranged through family connections and was uncommon. 
Table 4. Income inequality in Way Besay Watershed Lampung in 2004.

\begin{tabular}{|c|c|c|c|c|c|c|}
\hline & & Lewi Monyet & & & Rigis Jaya & \\
\hline Source of income & $\begin{array}{c}\text { Income } \\
\text { share }\end{array}$ & $\begin{array}{l}\text { coefficient } \\
\text { concentration }\end{array}$ & $\begin{array}{c}\text { Pseudo } \\
\text { Gini ratio }\end{array}$ & $\begin{array}{l}\text { Income } \\
\text { share }\end{array}$ & $\begin{array}{l}\text { coefficient } \\
\text { concentration }\end{array}$ & $\begin{array}{l}\text { Pseudo } \\
\text { Gini ratio }\end{array}$ \\
\hline \multicolumn{7}{|l|}{ A. Farm income } \\
\hline $\begin{array}{l}\text { Coffee garden } \\
\text { on state land }\end{array}$ & 0.41 & 0.99 & 0.37 & 0.20 & 0.50 & 0.19 \\
\hline $\begin{array}{l}\text { Coffee garden } \\
\text { on private land }\end{array}$ & 0.14 & 1.78 & 0.67 & 0.31 & 1.53 & 0.58 \\
\hline $\begin{array}{l}\text { Tenancy } \\
\text { coffee garden }\end{array}$ & 0 & 0 & 0 & 0.03 & 1.97 & 0.74 \\
\hline Rice field & 0.06 & 0.88 & 0.33 & 0.02 & 0.26 & 0.10 \\
\hline $\begin{array}{l}\text { Other farm } \\
\text { income }\end{array}$ & 0.11 & 1.02 & 0.38 & 0.18 & 0.45 & 0.17 \\
\hline B. Nonfarm income & 0.10 & 2.22 & 0.84 & 0.07 & 1.05 & 1.40 \\
\hline \multicolumn{7}{|l|}{ C. Wages } \\
\hline Agriculture & 0.13 & -0.33 & -0.13 & 0.11 & -0.79 & -0.30 \\
\hline Nonagriculture & 0.03 & -0.06 & -0.22 & 0.05 & 1.43 & 0.54 \\
\hline \multicolumn{7}{|l|}{ D. Other income } \\
\hline Transfers & 0.02 & 0.21 & 0.08 & 0.04 & 0.55 & 0.21 \\
\hline E. Total income & & & 0.38 & & & 0.30 \\
\hline
\end{tabular}

\section{Land management and environmental services} indicators

Based on the structure of existing vegetation, most coffee gardens in the study sites are multistrata coffee. The percentage of noncoffee trees was higher on farms inside protected forests $(10-11 \%)$ than on farms on private land (5-10\%). In Rigis Jaya, this was probably because of the community forestry program (HKM) that allows farmers to obtain land rights in protected forests. This program requires farmers to establish multistrata coffee systems for which they receive tree seedlings from the government. In Leuwi Monyet, farmers were still in the process of applying for HKM, but the program has influenced them to plant more trees in their coffee gardens.

Tree cover can be used as an estimator of ecosystem services. This multistrata system provides a complex canopy that protects the soil surface and creates tree litter on the garden floor. As a result, it can reduce the erosive force of water caused by both surface run-off and heavy raindrops and also provides soil nutrients. Coffee and shade trees such as Gamal (Gliricidia sepium) have a low index of shallowness (IS). This indicates that coffee grown in full sun and simple shade systems have shallow 
Table 5. Land inequality in Way Besay Watershed Lampung in 2004.

\begin{tabular}{|c|c|c|c|c|c|c|}
\hline & & Lewi Monyet & & & Rigis Jaya & \\
\hline Land status & $\begin{array}{c}\text { Income } \\
\text { share }\end{array}$ & $\begin{array}{l}\text { coefficient } \\
\text { concentration }\end{array}$ & $\begin{array}{c}\text { Pseudo } \\
\text { Gini ratio }\end{array}$ & $\begin{array}{c}\text { Income } \\
\text { share }\end{array}$ & $\begin{array}{l}\text { coefficient } \\
\text { concentration }\end{array}$ & $\begin{array}{l}\text { Pseudo } \\
\text { Gini ratio }\end{array}$ \\
\hline State land & 0.86 & 0.94 & 0.36 & 0.54 & 0.58 & 0.19 \\
\hline Private land & 0.13 & 1.44 & 0.56 & 0.38 & 1.41 & 0.46 \\
\hline Tenancy & 0.01 & 0.17 & 0.07 & 0.08 & 1.87 & 0.61 \\
\hline Total & & & 0.39 & & & 0.32 \\
\hline
\end{tabular}

roots that are only good for reducing soil erosion. However, most other trees species have a higher IS. Petai (Parkia speciosa), Sonokeling (Dalbergia latifolia), Melinjo (Gnetum gnemon), and jackfruit (Artocarpus heterophyllus) have the four highest indices of shallowness (Fig. 2). Some leguminous shade trees mentioned above that are often planted in coffee multistrata systems, such as Gamal, Erthrina sububram, Leucaena leucocephala, and Petai, also help increase soil nitrogen. The rate of decomposition of the litter layers from these types of trees is also high, which is good for improving soil fertility (Hairiah et al. 2005).

The mixture of tree species in coffee agroforestry system results in different patterns of rooting depth that provide good protection to the soil surface and also increase the stability of river banks (K. Hairiah, Widianto, D. Suprayogo, N. D. Lestari, V. Kurniasari, A. Santosa, B. Verbist, and M. Van Noordwijk, unpublished manuscript). A combination of deep-rooted trees for anchoring and shallowrooted trees or grass with a high root density for stabilizing topsoil is generally perceived to stabilize slopes prone to mass movement per layers. This implies that coffee multistrata provide better environmental services through water and soil conservation than do sun coffee and simple shade systems. Multistrata also retain soil nutrients by reducing and minimizing the risk of landslides and improve soil fertility by increasing the amount ot nitrogen in the soil.

\section{CONCLUSIONS}

Local people and migrants occupy the Sumberjaya watershed. They live in areas that range from forest conversion zones through coffee agroforest to degraded land, which together provide fairly good but threatened environmental services. Land security problems and conflicts occur in this area. Among the other indicators, this study found that their financial poverty was obvious. Our respondents' income per capita per day was below the international poverty line. Their education level was also low and below the provincial average. However, these poor farmers had provided environmental services by establishing coffee multistrata in the upstream areas; these systems allowed them to earn income while also preserving watershed functions similar to those of undisturbed forests. The income from these activities in state forests was also more equally distributed across communities than was income from private land, which suggests that these systems are also more effective in alleviating the poverty of those living on degraded forest land.

Insecure land rights were, however, a problem for poor farmers cultivating multistrata coffee in state forests. Land rights as a reward mechanism seem to work well in establishing and supporting environmentally friendly land management in protected forests. This was indicated by the lack of significant difference in management practices in protected forests and on private land. 
Payment for environmental services (PES) is assumed to contribute to reducing poverty through the payments themselves, which are thought to go mainly to poverty-stricken land users, as can be seen most explicitly in the RUPES (Rewarding Upland Poor for Environmental Services) program. In this case, income from PES might have a positive impact on local livelihoods if opportunity and transaction costs are carefully considered. The specific characteristics of PES programs and the areas in which they are implemented are likely to shape the relationship between PES and poverty alleviation (Pagiola et al. 2005). Rewarding poor communities in Sumberjaya watershed with land rights within state-owned and protected forests would not only reduce poverty but also increase equity among communities and households. This would enhance farmers' livelihoods and simultaneously improve their environment.

PES can be integrated into national park policy. Indonesia's national parks are managed through a zoning system, whereby the park area is divided into various use zones, such as core conservation zones and community use zones. PES can be given to farmers for managing community use zones, for guarding natural forests in core zones, and for stewardship in community use zones.

Responses to this article can be read online at: http://www.ecologyandsociety.org/vol12/iss2/art13/responses/

\section{Acknowledgments:}

The support of the RUPES Program under the International Fund for Agriculture and Development (IFAD) grant is gratefully acknowledged. The research results reported here is part of that study. We are grateful to Dr. Meine van Noordwijk for insightful comments and to Dudi Nugroho for map design. We also thank Mufti Mubarak and Edwin Jonson for their excellent assistance during fieldwork, along with Kamad and his family for their support in the field. We are indebted to all Leuwi Monyet and Rigis Jaya farmers for their patience, cooperation, and hospitality in the field. We also thank Trudy O'Connor for editing the English.

\section{LITERATURE CITED}

Alderman, H., and M. Garcia. 1993. Poverty, household food security, and nutrition in rural Pakistan. Research Report No. 96. International Food Policy Research Institute, Washington, D.C., USA.

Biro Pusat Statistik. 2002. Statistik Kesejahteraan. Biro Pusat Statistik, Jakarta, Indonesia.

Buana, R. Y., S. Suyanto, and D. K. Hairiah. 2006. Kebun Lindung: Kajian Ekologis dan Sosioekonomi di Lampung Barat, Sumatra. Agrivita 27 (3):170-181.

Fei, J. C. H., G. Ranis, and S. W. Y. Kuo. 1978. Growth and family distribution of income by factor component. Quarterly Journal of Economics 92:17-53.

Hairiah, K., D. Suprayogo, Widianot, and C. Prayogo. 2005. Trees that produce mulch layers which reduce run-off and soil loss in coffee multistrata systems. Available online at: http://www .icraf.cgiar.org/sea/Publications/files/bookchapter/ BC0150-05.pdf.

Pagiola, S., A. Arcenas, and G. Platais. 2005. Can payments for environmental services help reduce poverty? An exploration of the issues and the evidence to date from Latin America. World Development 33(2): 237-253.

Pagiola, S., and G. Platais. 2002. Payments for environmental services. Environmental Strategy Notes No. 3. World Bank, Washington, D.C., USA.

Pradhan, M., A. Suryahadi, S. Sumarto, and L. Pritchett. 2000. Measurements of poverty in Indonesia: 1996, 1999, and beyond. Social Monitoring and Early Response Unit Working Paper, June 2000. Available online at: http://www. smeru.or.id/report/workpaper/measurement/measbyond. pdf.

Pyatt, G., C. Chen, and J. Fei. 1980. The distribution of income by factor components. Quaterly Journal of Economics 95(3):451-473.

Rosa, H., S. Kandel, and L. Dimas. 2004. Compensation for ecosystem services and rural communities: lessons from the Americas. Programa Salvadoreño de Investigación sobre Desarrollo y 
Medio Ambiente (PRISMA), San Salvador, El Salvador.

Suyanto, S., R. P. Permana, N. Khususiyah, and L. Joshi. 2005. Role of land tenure in adopting agroforestry and reducing wild fire in a forest zone in Lampung-Sumatra. Agroforestry Systems 65:1-11.

Van Noordwijk, M. and P. Purnomosidhi. 1995.

Root architecture in relation to tree-soil-crop interactions and shoot pruning in agroforestry. Agroforestry Systems 30:161-173.

Van Noordwijk, M. 2005. RUPES typology for environmental services worthy of reward. RUPES Working Paper. World Agroforestry Centre, Nairobi, Kenya. Available online at: http://www.w orldagroforestrycentre.org/Sea/Networks/RUPES/ download/Working\%20 Paper/RUPES Typology. pdf.

Van Noordwjik, M., F. Agus, D. Suprayogo, K. Hairah, G. Pasya, B. Verbist, and Farida. 2004. Peranan Agroforestri dalam mempertahankan fungsi hidrologi daerah aliran sungai (DAS). Agrivita 26(1):1-8. 


\section{APPENDIX 1. GINI DECOMPOSITION}

The Gini decomposition formula was developed by Fei et al. (1978) and Pyatt et al. (1980). It can be written as follows:

$$
G(Y)=s_{\mathrm{i}} R\left(Y, Y_{\mathrm{i}}\right) G\left(Y_{\mathrm{i}}\right)
$$

where $G(Y)$ is the Gini ratio of total income, $Y_{\mathrm{i}}$ is income from income source $i, s_{\mathrm{i}}$ is share of income source $i, R\left(Y, Y_{\mathrm{i}}\right)$ equals the rank correlation ratio, and $G\left(Y_{\mathrm{i}}\right)$ equals the Gini ratio of income source $i . R\left(Y, Y_{\mathrm{i}}\right)$ is the rank correlation ratio expressed as:

$$
R\left(Y, Y_{\mathrm{i}}\right)=\operatorname{Cov}\left\{Y_{\mathrm{i}, \mathrm{r}}(Y)\right\} / \operatorname{Cov}\left\{Y_{\mathrm{i}, \mathrm{r}}\left(Y_{\mathrm{i}}\right)\right\}
$$

where $r(Y)$ is the ranking of households in terms of total income and $r\left(Y_{i}\right)$ is ranking of income source $i$.

Moreover, Alderman and Gracia (1993) elucidated the decomposition of the Gini coefficient with the following expression:

$$
\left.g_{\mathrm{i}}=R\left(Y, Y_{\mathrm{i}}\right) G\left(Y_{\mathrm{i}}\right)\right\} / G(Y)
$$

$\sum s_{\mathrm{i}} g_{\mathrm{i}}=1$ where $g_{\mathrm{i}}$ is the relative concentration coefficient of income source $i$ in overall inequality.

To determine whether income source $i$ increases or decreases inequality, we compare the relative concentration coefficient $g_{\mathrm{i}}$ to unity. 